\title{
Accounting
}

\section{The relationship between level of environmental financial accounting practices and financial performance in Vietnam}

\author{
La Soa Nguyen ${ }^{a *}$, Manh Dung Tran ${ }^{a}$ and Thi Hue Dang ${ }^{b}$
}

\begin{tabular}{l}
${ }^{a}$ National Economics University, \\
${ }^{b}$ University of Transport Technolog \\
\hline C H R O N I C L E \\
\hline Article history: \\
Received February 22019 \\
Received in revised format \\
February 272020 \\
Accepted March 82020 \\
Available online \\
March 82020 \\
\hline Keywords: \\
Environment accounting \\
Information disclosure \\
Finance performance \\
Accounting information
\end{tabular}
A B S T R A C T

This research is conducted for assessing the relationship between the level of environmental financial accounting practices (EFAP) and financial performance (FP) of listed firms. Data were collected from listed firms on Vietnam Stock Exchange for the period from 2013 to 2017, including the firms disclosed and not disclose EFAP. Ordinary least square (OLS), fixed effect model (FEM), and random effect model were employed for processing the data. The results reveal that there is a close relationship between the EFAP and financial performance. In addition, there is a difference in financial performance between the group of firms disclosed and not disclosed EFAP. Based on the findings, some recommendations are given for motivating EFAP in the listed firms for improving financial performance.

(C) 2020 by the authors; licensee Growing Science, Canada

\section{Introduction}

Many large corporations in the world such as Formosa, British Petroleum (BP), Volkswagen have collapsed due to fraud in information disclosure related to environmental protection (Ting, 2017). It is also a warning bell for firms to raise awareness of environmental protection and publicize environmental information to related parties. These failures and continuous business scandals have proved the need to practice environmental financial accounting for meeting the information needs of users. Transparent information about the environment is a way for businesses to create trust from stakeholders, improve the image and reputation of firms in the competition to attract investment (Vo et al., 2018). The higher level of disclosure of environmental information in annual reports not only helps firms improve their financial performance but also attracts a positive response from investors (Al-Tuwaijri et al., 2004). Firms should not consider the practice and disclosure of environmental accounting information to increase costs and reduce profits. In fact, practicing environmental accounting and information disclosure will help firms improve the financial performance of the company (Magness 2006; Qiu et al. 2016; Hitt et al., 2017; Yang \& Liang 2017). Firms listed publicly on Vietnam Stock Exchange should consider practicing environmental accounting and publicizing environmental information on annual reports as a sense of responsibility and implementation of the community. This is also the reason for the business community in the countries participating in The Comprehensive and Progress Agreement for TransPacific Partnership (CPTPP) cannot ignore the disclosure of information about activities and measures to protect environment. Vietnam is a member of the CPTPP agreement, so the implementation and disclosure of environmental accounting information

* Corresponding author.

E-mail address: $\underline{\text { Soanl@neu.edu.vn }}$ (L.S. Nguyen) 
by Vietnamese firms is considered as a key factor. It is also a necessary condition helping firms improve competitive capacity and develop sustainably in the context of global economic integration. In general, the survey confirms a lack of knowledge and awareness of EFAP of listed firms on Vietnam Stock Exchange (Nguyen et al., 2017; Nguyen et al., 2018a; Nguyen \& Tran 2019). Research results indicate that most firms do not meet the demand for information on environmental accounting as expected by stakeholders, so there is a need to improve the level of EFAP. Even though the number of studies on EFAP is high, an empirical examination of the relationship between EFAP and financial performance in the emerging markets context is limited. The lack of empirical studies on this issue could be one of the factors in explaining why firms listed on the Vietnam Stock Exchange are less concerned or involved in promoting their EFAP to various stakeholder groups (Ho et al. 2017). Thus, by using Environmental information disclosure on annual report as measurement of EFAP, this study is an effort to fill the gap by empirically examining the relationship between EFAP and financial performance in Vietnamese context.

The remainder of the paper is organized as follows: In Section 2, Theoretical Background and Research Hypotheses; Section 3 presents the Research Methodology; Section 4 presents Results and Discussion about the relationship between EFAP and financial performance. Conclusion and Recommendations are explained in Section 5.

\section{Theoretical background and research hypotheses}

\subsection{Relationship between the level of environmental financial accounting practices and financial performance}

Environmental accounting is judged in two aspects, accounting and environmental management. In addition to supporting internal decision making in the business operations of the business with the view to improve financial and environmental performance, environmental accounting also provides information outside the business to stakeholders (banks, financial institutions, environmental management agencies, communities, etc.). Thereby it helps businesses to (i) Enhance competitive advantage due to green consumption of clean products; (Al-Tuwaijri et al., 2004). Change and increase the level of awareness and action of organizations and stakeholders on environmental issues in each firm and the economy as a whole.

The collapse of major economic corporations in the world due to fraud in disclosing environmental information of products has demonstrated the necessity of environmental accounting practice. To explain the need of environmental financial accounting practices, and the relationship between the level of environmental financial accounting practices and financial performance, scientists often use the following theory:

- Friedman's trade-off theory: According to this theory, implementing social responsibility is the most effective way for businesses to increase profits. Although, when firms are engaged in social and environmental activities, they incur additional costs and reduces income, but in return, businesses improve their reputation and image to attract investors (Dowling \& Pfeffer, 1975). The higher the level of implementation of environmental and social responsibilities, the higher the business efficiency and will limit the scandals that businesses may encounter.

- Theory of supply and demand of McWilliams and Siegel: According to this theory, the need for firms to fulfill their social responsibilities is to increase business efficiency and minimize risks from related parties' lawsuits (Guthrie \& Parker 1989). Stakeholders have a need to provide information related to social and environmental responsibility, so firms will implement environmental accounting to meet this information needs. Satisfying the needs of stakeholders will be favorable for businesses and minimize the risks that occur.

- Social impact theory of Cornell and Shapiro: According to this theory, improving environmental protection and social responsibility will attract investors' attention (Guthrie \& Parker 1989). Therefore, the expected benefits from implementing social responsibility will exceed the implementation cost. This theory supports the positive relationship between social responsibility and financial efficiency and the negative relationship between social responsibility and financial risk. Some of the reasons for improving corporate social responsibility are that they will improve their business reputation, improve relationships with financial institutions, and reduce the company's risk.

- Stakeholder theory: This theory is derived from the perspective of economic interests in all actions by the economist Friedman (1984). According to Freeman (1984), all stakeholders are affected by all business behaviors, including shareholders, suppliers, customers, employees, competitors, social workers, lawmakers, academics, indigenous peoples, labor organizations, local administration and the government. Based on stakeholder theory, (Ullmann, 1985) explains that if a stakeholder controls an important source of business, the business will find a way to satisfy their needs. Environmental financial accounting practices are considered an effective governance strategy that addresses relationships and satisfies needs of stakeholders. On the other hand, the study by (Chiu and Wang 2014) shows that return on equity (Guenster et al., 2011) is positive and debt to equity ratio is reverse to the disclosure of environmental financial accounting practices. 


\subsection{Measurement of financial performance}

Previous studies have suggested that the firm's financial performance can be measured in the ways of accounting-based or market-based methodology.

(i) Accounting based approach: Use accounting metrics such as return on assets (ROA), return on equity (Guenster et al., 2011) or financial analysis of a firm (Horváthová, 2012). These indicators may reflect the performance of the firm at an overall level but do not observe the multinational characteristics of the firm's production process. Some accounting-based measures have been employed to assess financial performance including ROA, ROE and return on sales (ROS) (Nelling \& Webb, 2009). The reason for using these three variables to measure financial performance is that these data are less likely to be manipulated, and are also the most commonly used measures for financial performance. But the inherent limitations of accounting-based measures are that they only capture historical data on financial performance. Moreover, the data may be distorted by the different management perceptions and accounting procedures used by different firms.

(ii) Market based approach: Some studies use market metrics (Boaventura et al., 2012). Because the measure of market based financial performance avoids some accounting constraints as it shows future factors and focuses on market efficiency. These measures are less relevant to accounting procedures and are an indicator of the investor's choice to evaluate a firm's ability to generate future profits. The use of market-based measures indicates that evaluating the financial performance of investors is a good measure of performance (Nguyen et al. 2018b). However, the use of stocks as market-based measures of financial performance also have limitations. In addition, a number of studies have used both accounting data and market data (Ahmed \& Habib 2015) with three variables such as ROA, stock market return, and Tobin's q. In addition, (Nelling and Webb 2009) use stock return as a dependent variable to measure financial performance. (Simpson and Kohers 2002)argue that both accounting and market indicators can be applied to measure the financial performance of a firm, each of which depends on certain trends.

\subsection{Research hypotheses}

According to the profit motive theory, investment in sustainable development in general and investment in environmental accounting disclosure in particular will change the financial results of the business in the future (Ullmann, 1985). For example, investing in transparency and disclosure of information related to environmental accounting will increase the image of the business with the community, with stakeholders, thereby increasing revenue, market share, or will attract more qualified and ethical staff to work at the unit, or reduce unwanted conflicts with stakeholders, or avoid legal troubles. Direct or indirect damage to the environment will likely result in the loss of credibility in the consumer's eyes (Simpson \& Kohers, 2002). In fact, customers have come and gone back to businesses that create a good image in the eyes of consumers about the sense of protection and preservation of the environment. Controlling and disseminating environmental information is one of the key elements of business credibility, which is to satisfy and strengthen the trust of stakeholders (Ali et al., 2004). At the same time, implementing environmental accounting also brings to the firm a noteworthy income such as subsidies, bonuses from environmental protection investments, the difference from cost cutting advances in the process, minimizing waste disposal costs; proceeds from sales of waste materials, disposal of waste, etc. (Jamil et al., 2015).

Recently, studies related to corporate social responsibility in general and environmental responsibility in particular have measured the relationship between corporate social responsibility and financial performance. Financial analysis based on the actual data from the financial accounting of firms. These results indicate that corporate social responsibility can improve a firm's competitiveness over the long term, implying a positive relationship between corporate social responsibility involvement and the financial performance of that enterprise (Qiu et al., 2016). Many empirical studies have found a similar relationship between environmental responsibility and financial performance (Simpson \& Kohers, 2002; Al-Tuwaijri et al., 2004; Qiu et al., 2016). Dowling and Pfeffer (1975) define profit as an important element in the disclosure of corporate environmental responsibility practices. Barakat et al. (2015) also found a meaningful relationship between environmental responsibility and financial performance, and argued that firms with good financial performance will have more resources. In order to deal with social problems, these two variables have the potential to influence one another. However, in contrast, Waddock and Graves (1997) provide a summary of previous research findings on negative correlations, positive and non-correlated correlations. It also suggests that disclosure of social responsibility information will increase costs and reduce financial performance. In addition, Nelling and Webb (2009) argue that there is no relationship between social responsibility and financial performance.

Thus, in view of the different empirical studies on the different relationships between social responsibility and financial performance. Therefore, to examine the relationship between the level of disclosure of environmental accounting information and the financial performance of listed firms in Vietnam, as well as how to consider the relationship, we give a hypothesis as:

H1a: There is a positive relationship between the disclosure level of the environmental accounting information and the financial performance of the company in the current year. 
622

H1b: There is a positive relationship between the disclosure level of environmental accounting information and the financial performance of the company in the following year.

There is a lot of empirical supports for the view that firms will be fined if they see business management in ways that conflict with social values. This is especially true when the conflict arises between pursuing organizational profits and the goal of environmental protection. Thus, one of the ways firms risk management in the process of operating and improving financial performance is to engage in socially and socially responsible behavior. (Isanzu and Fengju 2016) investigate the impact of social responsibility on financial performance by comparing financial performance (ROA, ROE) through an average t-test of a sample of 50 firms disclosed social responsibility and 51 firms did not, the results of social responsibility have the same impact on the financial performance of firms that disclosed high social responsibility than the firms did not. (Poddi and Vergalli 2016) investigate the relationship between corporate social responsibility and firm efficiencies by analyzing the strategic graphs among non-public liability firms. The results show that there are some differences in some economic indicators between firms that disclose social responsibility and firms that do not disclose corporate social responsibility. In order to better understand the relationship between social responsibility and financial performance of Vietnamese listed firms, this study investigates financial performance between listed firms have disclosed environmental accounting information and listed firms have not disclosed environmental accounting information for assessing the impact of social responsibility on financial performance as well as the benefits that corporate social responsibility. So we give a hypothesis as:

H2: There are financial performance differences between listed firms disclosing environmental financial accounting practices and listed firms not disclosing without environmental financial accounting practices.

\section{Research methodology}

\subsection{Data collection}

Group 1: Listed firms disclosed environmental financial accounting practices

The selected firms meet two criteria. i.e. (i) having a complete set of annual accounting data for the five years 2013 - 2017 (after the time when Global Reporting Initiative's (2013) Sustainable Development Report Guidelines are issued); (Al-Tuwaijri et al. 9 2004) firms disclosed environmental accounting information in their annual reports or sustainability reports. The final sample for this study was unbalanced data, as shown in Table 1.

Table 1

Research statistics of the sample

\begin{tabular}{|c|c|c|c|c|c|c|}
\hline \multirow[t]{2}{*}{ No. } & \multirow[t]{2}{*}{ Sectors } & \multicolumn{5}{|c|}{ Number of listed firms with environmental financial accounting practices } \\
\hline & & 2013 & 2014 & 2015 & 2016 & 2017 \\
\hline 1 & Agriculture - Forestry - Fishery & 1 & 6 & 12 & 14 & 25 \\
\hline 2 & Mining & 5 & 12 & 14 & 16 & 27 \\
\hline 3 & Community utilities & 2 & 3 & 6 & 8 & 12 \\
\hline 4 & Construction and real estate & 0 & 0 & 5 & 6 & 11 \\
\hline 5 & Manufacturing & 2 & 4 & 9 & 14 & 30 \\
\hline & Total & 10 & 25 & 46 & 58 & 105 \\
\hline
\end{tabular}

Group 2: Listed firms did not disclose environmental financial accounting practices

These firms meet two criteria, i.e. (i) a complete annual accounting data sheet covering the five years (2013-2017). ii) Firms correspond to the size, sector and time of listing with Group 1 firms.

\subsection{Variable measurements}

\section{Level of environmental financial accounting practices (EFCP)}

According to the Global Reporting Initiative's (2013), the total number of items for disclosure of mandatory environmental accounting information is 34 items in the twelve relevant fields presented in Table 2, below:

\section{Table 2}

Items for mandatory environmental information disclosure

\begin{tabular}{clc|cl}
\hline No. & Field & $\begin{array}{c}\text { No. of items have to be } \\
\text { disclosed }\end{array}$ & No. & \multicolumn{1}{c}{$\begin{array}{c}\text { Fo. of items have to be } \\
\text { disclosed }\end{array}$} \\
\hline 1 & Material & 2 & 7 & Information on label of products and services \\
2 & Energy & 5 & 8 & Compliance \\
3 & Water & 3 & 9 & Transportation \\
4 & Biodiversity & 4 & 10 & Overall \\
5 & Emissions & 7 & 11 & Supplier's Review of the Environment \\
6 & Wastewater and Waste & 5 & 12 & Environmental complaints mechanism \\
\hline
\end{tabular}


Depends on how the firm has disclosed relevant information on the annual report for assessing the scored for the level of environmental financial accounting practices (EFCP) in Table 3 below:

Table 3

Methods to assess levels of environmental financial accounting practices

\begin{tabular}{l}
\hline \multicolumn{1}{c}{ Level of information disclosure } \\
\hline Disclosure of information is both quantitative and qualitative \\
Only qualitative, and non - quantitative disclosure \\
Quantitative information both in object and value, and no qualitative information \\
Quantitative information on the value, and no object and no qualitative information \\
No information disclosure
\end{tabular}

EFCP is calculated according to the weighted approach, depending on the quality of the information provided to assess the score for each item, then averaged for each category and calculated the level of environmental financial accounting practice. The formula is as follows: The level of environmental financial accounting practice of firms $\mathrm{X}=\frac{\sum_{i=1}^{34} Y i}{34}(Y i$ is the score of information item $i$ published by firm $\mathrm{X}$ ).

\subsection{Financial performance}

To measure financial performance, this research employs an accounting-based approach and and a market-based metric, and two indicators representing financial performance were ROA (ROA $\left.=\frac{\text { Profitaptertax }}{\text { Total Assets }}\right)$ and Tobin'q (TBQ = $\frac{\text { Liabilities+ Market price of equity }}{\text { Total Assets }}$ ) (Ahmed and Habib 2015). The reason for choosing of these two indicators is because they are the ones most practiced in previous studies.

\subsection{Control variables}

There have been quite a number of studies on the determinants influencing the financial performance of firms such as (Boaventura et al. g 2012). These studies showed that many determinants affecting the financial performance of firms such as the percentage of state capital, financial leverage, management competence, firm size, cash flow, the ratio of the market value to book value of total, assets quick ratio, business cycle, listing period, independent auditing, debt ratio and others. In order to examine the relationship between social responsibility practice and financial performance, prior studies have also used control variables besides independent variables such as the percentage of state capital, financial leverage, cash flow, the ratio of the market value to book value of total, debt ratio, independent auditing (Simpson \& Kohers, 2002; Al-Tuwaijri et al., 2004; Qiu et al., 2016). These studies have demonstrated that above factors significantly impact on financial performance. Besides, due to data collection limitations, we use six control variables in the model to investigate the relationship between EFCP and financial performance including firm size (SIZE); financial leverage (LEV); listing period (AGE); independent auditing (AUD); cash flow (CF); market value ratio (MV).

\section{Table 4}

Control variable measurement

\begin{tabular}{lll}
\multicolumn{1}{c}{ Code } & \multicolumn{1}{c}{ Control Variables } & \\
\hline SIZE & Business Size & Log (Total Assets) \\
LEV & Financial leverage & Total long-term debt divided by total assets \\
AGE & Listing period & Number of years from the beginning of listing to the end of 2017 \\
AUD & Independent Auditing & $=1$, independent auditor of Big 4; $=0$, the rest \\
CF & Cash flow & Cash flow from operations/total assets \\
MV & Market value ratio & (Total assets - book equity + market equity)/total assets \\
\hline
\end{tabular}

To examine the relationship between the level of environmental financial accounting practices and financial performance of listed firms, we design the following regression models of

(i) Financial performance is a dependent variable, the level of environmental financial accounting practices and six control variables are independent variables. (Al-Tuwaijri et al., 2004) Additional latency determinants are employed form assessing the impact of prior year environmental financial accounting practices on financial performance. The study chose a one-year lag (t1) that was not many years ago due to the inadequate sample size. The research model is designed as below:

$$
\begin{aligned}
& C F T_{j t}=\beta 0+\beta 1 E F C P_{j t}+\beta 2 S I Z E_{j t}+\beta 3 L E V_{j t}+\beta 4 A G E_{j t}+\beta 5 A U D_{j t}+\beta 6 C F_{j t}+\beta 7 M V_{j t}+\boldsymbol{\varepsilon}_{j t} \\
& C F T_{j t}=£ 0+£ 1 E F C P_{j t-1}+£ 2 S I Z E_{j t}+£ 3 L E V_{j t}+£ 4 A G E_{j t}+£ 5 A U D_{j t}+£ 6 C F_{j t}+£ 7 M V_{j t}+f_{j t}
\end{aligned}
$$




\section{Results and discussion}

\subsection{Descriptive statistics}

Fig. 1 gives an overview of the level of environmental financial accounting practices by listed firms in Vietnam from 2013 to 2017. During the study period, Increasing market volatility is not only evidenced by the number of listed firms disclosing environmental accounting information (from 10 firms in 2013 to 105 firms in 2017), but also by indicator level of environmental financial accounting practices which is a good sign demonstrating that Vietnam firms are paying attention to release of information on environmental indicators. This is shown by the mean value of the environmental financial accounting practices indicators are growing steadily every year. However, the data also show that the level of environmental financial accounting practices between different industries is different, some firms focus on investing heavily in information and indicators, but this information has not been logically stated based on the assessments of stakeholders.

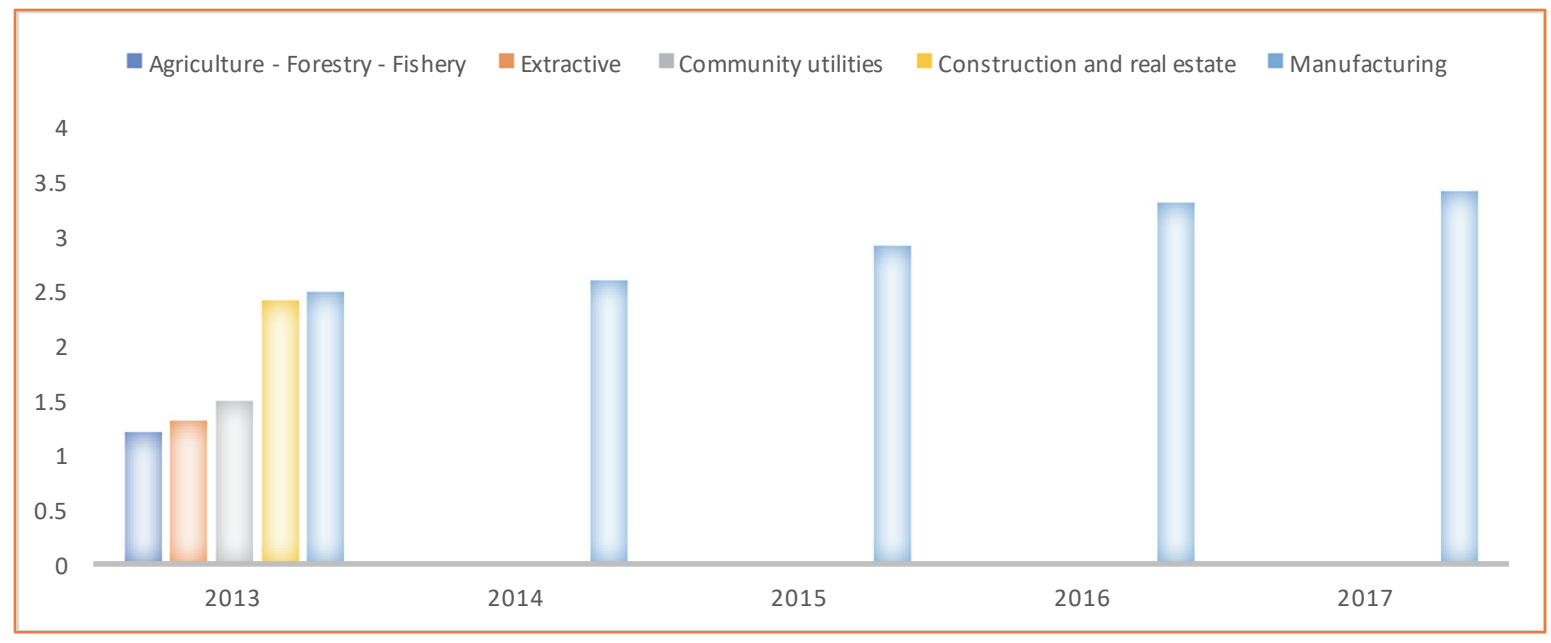

Fig. 1. Volatility of the index of environmental financial accounting practices of listed firms by industry

Table 5 presents basic statistical describing parameters of independent variables and dependent variables. According to (Tauchen, 1986), condition for estimation of reliability for performing regression analysis is $\mathrm{n}>200$. According to Hair et al. (2014), there should be 15-20 observations for a variable to be estimated. Combined with these principles, the sample size chosen with 244 observations is reasonable. The results in Table 5 show that the level of environmental financial accounting practices is 2.879 and range from 1.008 to 3.687. The size of the business ranges from 10.329 to 18.327 , indicating that the size of the firms in the sample differs widely. The period of listing on the stock market is 14.391 years on average and fluctuates from 9.865 to 17.710 , which proves that the listed firms in the sample are not too young.

Table 5

Statistical analysis

\begin{tabular}{|c|c|c|c|c|c|c|c|c|c|c|}
\hline & ROA & TBQ & $\mathrm{EFCP}_{t}$ & $\mathrm{EFCP}_{\mathrm{t}-1}$ & SIZE & LEV & AGE & AUD & $\mathrm{CF}$ & MV \\
\hline No. of Observations & 244 & 244 & 244 & 139 & 244 & 244 & 244 & 244 & 244 & 244 \\
\hline Mean value & .085 & 1.294 & 2.879 & 2.667 & 15.265 & .410 & 14.391 & .405 & .08 & 1.65 \\
\hline STD & .091 & 1.228 & 2.705 & 2.605 & 5.184 & .317 & 7.059 & .419 & .07 & 1.67 \\
\hline Min value & -.349 & .004 & 1.008 & 1.105 & 10.329 & .219 & 9.865 & .000 & .06 & 1.23 \\
\hline Max value & .796 & 6.652 & 3.687 & 3.287 & 18.327 & .683 & 17.710 & 1.000 & .12 & 2.3 \\
\hline
\end{tabular}

\subsection{Evaluation of correlation between variables}

Table 6 presents the results of the correlation coefficient test between the variables and the results of the multicollinearity test. The purpose of the correlation analysis is to examine the tendency of the relationship between independent and dependent variables in the model. The previous year's and the year's the level of environmental financial accounting practices are positively correlated with ROA and TBQ, meaning that the higher the level of environmental financial accounting practices, the higher financial efficiency in both present and future. However, to confirm whether the results are accurate or not, we need to conduct multivariate regression analysis. Table 6 also shows the results of the multicollinearity test. The results show that at the same time, the correlated pairs are less than 0.8 and the VIF of the independent variable is less than 5 , which proves that there is not multicollinearity. In addition, in order to increase the reliability of the regression results, we examine whether there was a change in variance in the research model through the use of the White's General test. The test results show that the P-value is greater than 0.05 , so with a significance level of $5 \%$ the $\mathrm{H}_{0}$ hypothesis on the uniformity of the variance is acceptable. It means that the pattern does not exist in the phenomenon of variance. With the above analysis, we assert that appropriate data to perform 
multivariate regression analysis for examining the relationship between the level of environmental financial accounting practices and financial performance.

Table 6

Correlation and multicallinearity test

\begin{tabular}{|c|c|c|c|c|c|c|c|c|c|c|c|c|}
\hline & ROA & TBQ & $\mathrm{EFCP}_{\mathrm{t}}$ & $\mathrm{EFCP}_{\mathrm{t}-1}$ & SIZE & LEV & $\mathrm{AGE}$ & AUD & $\mathrm{CF}$ & MV & $\mathrm{VIF}(\mathrm{t})$ & $\mathrm{VIF}(\mathrm{t}-1)$ \\
\hline $\mathrm{ROA}$ & 1 & & & & & & & & & & - & - \\
\hline TBQ & 0.512 & 1 & & & & & & & & & - & - \\
\hline $\mathrm{EFCP}_{\mathrm{t}}$ & 0.075 & 0.134 & 1 & & & & & & & & 2.125 & - \\
\hline $\mathrm{EFCP}_{\mathrm{t}-1}$ & 0.624 & 0.467 & 0.036 & 1 & & & & & & & - & 2.013 \\
\hline SIZE & -0.230 & 0.057 & -0.452 & -0.089 & 1 & & & & & & 2.608 & 2.821 \\
\hline LEV & -0.543 & 0.108 & 0.147 & -0.176 & 0.133 & 1 & & & & & 1.721 & 1.901 \\
\hline AGE & 0.537 & 0.215 & 0.268 & 0.167 & 0.189 & 0.154 & 1 & & & & 1.009 & 1.827 \\
\hline AUD & 0.289 & 0.271 & 0.195 & 0.142 & 0.221 & 0.143 & 0.127 & 1 & & & 1.716 & 1.871 \\
\hline $\mathrm{CF}$ & -0.210 & 0.017 & -0.252 & 0.116 & 0.163 & 0.137 & 0.318 & 0.219 & 1 & & 2.812 & 2.802 \\
\hline MV & -0.547 & 0.108 & 0.135 & -0.213 & 0.145 & 0.182 & 0.416 & 0.419 & 0.134 & 1 & 1.908 & 1.834 \\
\hline
\end{tabular}

\section{Discussions}

The relationship between the level of environmental financial accounting practices and financial performance of the current year

Table 7 presents the results of regression using the least squares (OLS), fixed effects model (FEM) and random effects model (Ciftci et al.). The results show that there are differences among three models. Which model is best suited for the case where ROA is a dependent variable and TBQ is a dependent variable. We conduct the Breusch-Pagan Lagrange test; Hausman test; and F_test, the test results are as below:

(i) ROA is a dependent variable

For the results of the Breusch-Pagan Lagrange test, the accepted hypothesis $\mathrm{H}_{0}$ (Prob $\left.=1.0000\right)$ thus the pooled OLS model is more appropriate than the REM model. For the Hausman test, rejecting the hypothesis $\mathrm{H}_{0}($ Prob $=0.0444)$ meaning that the FEM model is more appropriate than the REM model. However, based on F-test results (Prob $=0.4620$ ), it is also assumed that the fit model is pooled OLS. Thus, the final fit model to measure this relationship is the pooled OLS model, with a $1 \%$ significance level. The results in Table 7 (Sig. $=0.0412<0.05)$ show that the level of disclosure of environmental accounting information influences the current year's ROA.

(ii) TBQ is a dependent variable

For the results of the Breusch-Pagan Lagrange test, showing that rejecting the null hypothesis (Prob $=0.0000)$, the REM model is more appropriately pooled OLS. Similarly, for the Hausman test, the test also rejected the hypothesis $\mathrm{H}_{0}(\mathrm{Prob}=0.0000)$ that the FEM model was more appropriate than the REM model. At the same time, the F-test also shows that the FEM model is a suitable model $($ Prob $=0.0000)$. Therefore, the appropriate model for measuring this relationship is the FEM model. The results in Table 7 (Sig. $=0.1209>0.05$ ) show that the level of disclosure of environmental accounting information has no impact on the current year's TBQ.

Table 7

Regression results - The case without the latency factor

\begin{tabular}{|c|c|c|c|c|c|c|}
\hline & \multicolumn{3}{|c|}{$\mathrm{ROA}$} & \multicolumn{3}{|c|}{ TBQ } \\
\hline & OLS & FEM & REM & OLS & FEM & REM \\
\hline \multirow{2}{*}{$\mathrm{EFCP}_{\mathrm{t}}$} & 0.228 & 0.316 & 0.234 & 0.606 & 0.291 & 0.431 \\
\hline & $(.0412)$ & $(.0113)$ & $(.0243)$ & $(.0751)$ & $(.1209)$ & $(.1374)$ \\
\hline \multirow{2}{*}{ SIZE } & -0.316 & -0.706 & 0.272 & 0.518 & -0.736 & 0.280 \\
\hline & $(.0015)$ & $(.0054)$ & $(.0074)$ & $(.0031)$ & $(.0037)$ & $(.0017)$ \\
\hline \multirow{2}{*}{ LEV } & -0.227 & 0.056 & -0.482 & -0.837 & 0.184 & -0.186 \\
\hline & $(.0058)$ & $(.0345)$ & $(.0029)$ & $(.0043)$ & $(.0045)$ & $(.0025)$ \\
\hline \multirow{2}{*}{ AGE } & 0.331 & 0.165 & 0.192 & 0.243 & 0.229 & 0.563 \\
\hline & $(.0075)$ & $(.0027)$ & $(.0350)$ & $(.0036)$ & $(.0031)$ & $(.0057)$ \\
\hline \multirow{2}{*}{ AUD } & 0.967 & 0.247 & 0.596 & 0.167 & 0.452 & 0.431 \\
\hline & $(.0062)$ & $(.0032)$ & $(.0084)$ & $(.0030)$ & $(.0037)$ & $(.0076)$ \\
\hline \multirow{2}{*}{$\mathrm{CF}$} & -0.302 & -0.703 & -0.269 & 0.521 & -0.742 & 0.282 \\
\hline & $(.0021)$ & $(.0048)$ & $(.0067)$ & $(.0038)$ & $(.0041)$ & $(.0016)$ \\
\hline \multirow{2}{*}{ MV } & 0.313 & -0.701 & 0.269 & 0.526 & -0.741 & 0.269 \\
\hline & $(.0009)$ & $(.0049)$ & $(.0071)$ & $(.0041)$ & $(.0041)$ & $(.0020)$ \\
\hline Number of Obs & 244 & 244 & 244 & 244 & 244 & 244 \\
\hline Constant & 0.321 & 0.342 & 0.421 & 0.601 & 0.621 & 0.707 \\
\hline Adj R squares & 0.3312 & 0.3342 & 0.3642 & 0.4298 & 0.4329 & 0.4809 \\
\hline
\end{tabular}


Thus, the level of environmental financial accounting practices of listed firms on Vietnam securities market influences the financial performance according to the current year's accounting. The relationship between the level of environmental financial accounting practices and the financial performance of the current year. This result is contrary to the studies of (Isanzu and Fengju 2016; Nelling and Webb 2009; Ho et al. 2017). However, this is explained by the sensitivity of the Vietnamese stock market with financial accounting information disclosed.

The relationship between the level of environmental financial accounting practices and financial performance of the following year

To examine the relationship between the level of environmental financial accounting practices and financial performance of the following years, we perform a multivariate regression analysis with dependent variables of ROA and TBQ. The results of the regression analysis are presented in Table 8. Similarly, we also conduct Breusch-Pagan Lagrange test; Hausman test; and F_test, to choose the most suitable model to measure this relationship. The test results indicate that in the case of ROA as a dependent variable, the OLS model is best suited; in the case of TBQ as the dependent variable, the FEM model is sub-merged with the significance level of $5 \%$.

\section{Table 8}

Regression results - the case with the latency factor

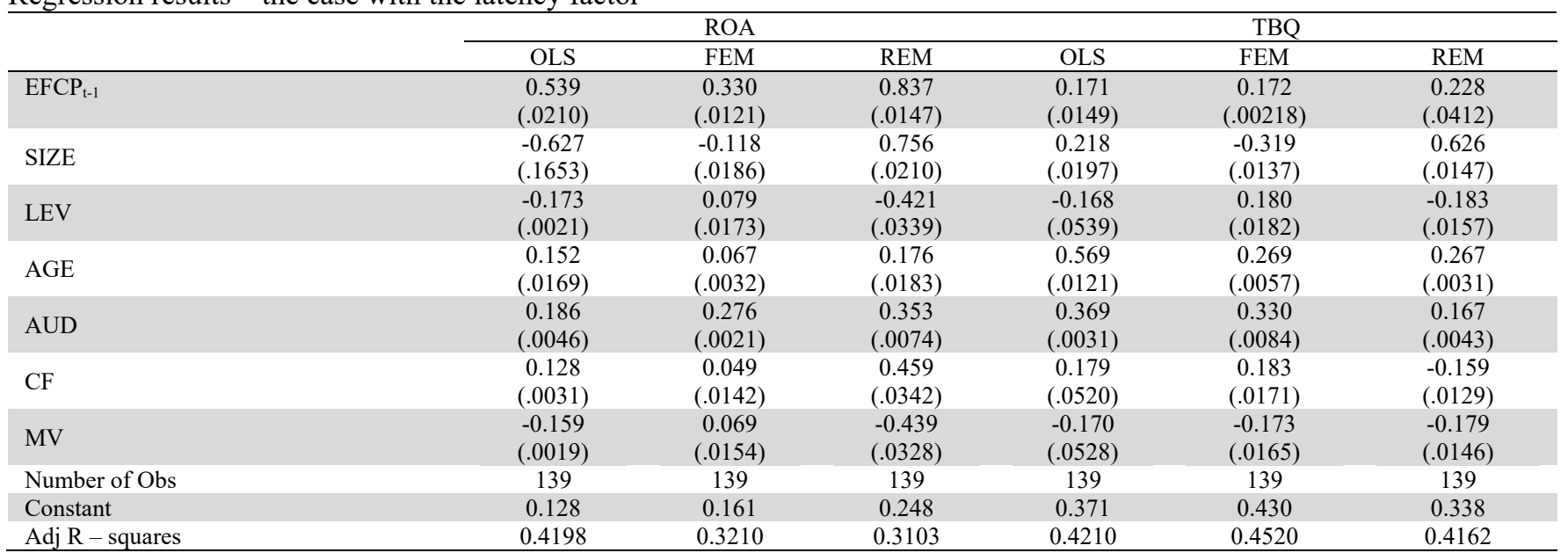

The results in Table 8 show that Sig. $=0.0210$ and Sig. $=0.0218$ to $<0.5$, there is a relationship between the level of environmental financial accounting practices and financial performance of the following year. As a result, the level of environmental financial accounting practices by listed firms influences financial performance according to the accounting and market of the following year. This result is consistent with studies (Isanzu \& Fengju, 2016; Nelling \& Webb, 2009; Ho et al., 2017). This shows that the clearer, more detailed and transparent disclosure of environmental accounting information is more conducive to the future financial performance of the business.

\section{The financial effect between listed firms disclosed environmental financial accounting practices and listed firms did not disclose}

This study examined the differences in financial performance between the two groups of firms, i.e. the group disclosed environmental financial accounting practices and the group did not. The results are presented in Table 9, showing financial performance of each group and the results of the t-test.

Table 9

Group financial performance and Bartlett's test for equal variances

\begin{tabular}{clcccc}
\hline & \multicolumn{1}{c}{ Group } & No & Mean & Std.Dev & Std.Err \\
\hline \multirow{2}{*}{ ROA } & EFCP & 105 & 0.08745 & 0.09675 & 0.00645 \\
& Non-EFCP & 105 & 0.06834 & 0.42317 & 0.02341 \\
\hline \multirow{2}{*}{ TBQ } & EFCP & 105 & 1.08466 & 0.86751 & 0.06123 \\
& Non - EFCP & 105 & 1.15328 & 2.01762 & 0.12657 \\
\hline
\end{tabular}

Table 10

The ANOVA and Bartlett's test

\begin{tabular}{cccccccc}
\hline & & \multirow{2}{*}{ Prob>F } & SS & df & MS & \multicolumn{2}{c}{ Bartlett's test } \\
& & & & & & Prob \\
\hline ROA & 2.59 & 0.0000 & 2.317 & 243 & 0.009 & 89.3856 & 0.001 \\
TBQ & 0.41 & 1.0000 & 1089.432 & 243 & 4.328 & 412.6549 & 0.000 \\
\hline
\end{tabular}


(i) if we use ROA: The mean value for group of listed firms disclosing environmental financial accounting practice $(0.087)$ is higher than for firms not disclosing environmental financial accounting practice (0.068). At the same time, t-test results show that $\mathrm{p}$-value $=0.000<0.05$. Thus, the hypothesis $\mathrm{H}_{0}$ is rejected and accepts the alternative hypothesis. This means that there is a statistically significant difference in ROA between listed firms disclosing environmental financial accounting practice and listed firms not disclosing.

(ii) If we use TBQ: The mean value for group of listed firms disclosing environmental financial accounting practice (1.084) is lower than for firms not disclosing environmental financial accounting practice $(1,153)$. At the same time, t-test results show that $\mathrm{p}$-value $=1.000>0.05$. Thus, the null hypothesis is accepted, meaning that there is no statistically significant difference in TBQ between listed firms disclosing environmental financial accounting practice and listed firms did not disclose.

Thus, when listed firms disclose environmental financial accounting practice in a detailed and transparent manner, it enhances the image, increases the value of the brand, promotes morale of employees, increases productivity, resulting in reduced transaction costs to obtain external funding.

\section{Conclusion and recommendations}

The findings have shown that there exists a relationship between the level of environmental financial accounting practices and financial performance of listed firms on Vietnam Stock Exchange. This result is similar to previous studies (Ho et al., 2017). In this study, there have been new points in comparison with prior studies as this study examined the impact of the level of environmental financial accounting practices on financial performance not only in the current year, but the following year. As a result, the level of environmental financial accounting practices in the current year is not only meaningful in improving financial performance of that year but also helps to improve the financial performance of the following year. In addition, this research examined and compared the financial performance of two groups of firms disclosing and not disclosing environmental accounting, the results show that there is a difference relative to financial performance between two groups and the mean of group 1 is higher than the mean of group 2. The results again confirm the benefits and implications of implementing environmental accounting. In other words, in the current context, the environmental financial accounting practices will help listed firms improve the financial performance. The higher the level of environmental financial accounting practices, the higher the corporate financial performance. From the findings, we propose some recommendations to Vietnam listed firms as below:

First, the need to raise awareness of corporate environmental responsibility and the benefits of disclosing detailed environmental accounting information to the financial performance. Some businesses say that if they focus on environmental protection activities, transparency of environmental accounting information is costly, reducing profits, it is a misconception. The empirical results of this study showed that the level of disclosure of environmental accounting information influences financial performance both in present year and the following year. Therefore, the disclosure of environmental accounting information is not only to be complied with environmental law, avoided legal complications but also improved the image and increased firm financial performance.

Second, in the Vietnamese context and in emerging context as well, the reporting of primary environmental accounting information is still voluntary and free of any general pattern, with only large firms reporting responsibility. The number of firms reporting social responsibility is very low. The results of this study are the basis for encouraging firms to change views when making annual reports as well as the content of disclosure in their annual reports should not be too focused on the indicators. Financial results achieved during the year that ignored the environmental performance achieved. Because, together with the trend of green development of the world, investors are more interested in the information related to the implementation of corporate social responsibility. Consequently, with the implementation of environmental responsibility, the disclosure of this information to investors is also a way to attract their attention.

Third, the results also show that, in addition to the level of disclosure of environmental accounting information, other determinants such as firm size, financial leverage, listing period, independent auditing also influence firm financial performance. Therefore, in order to achieve financial performance in the period, listed firms should consider, coordinate and pay attention to many factors in order to achieve the best economic growth while ensuring economic growth, sustainable development and image of firms in the market.

\section{References}

Ahmed, T., \& Habib, F. (2015). Does CSR enhance profitabilty?: Evidence from an emerging economy. International Journal of Engineering Technology, Management and Applied Sciences, 3, 424-429.

Al-Tuwaijri, S. A., Christensen, T. E., \& Hughes Ii, K. E. (2004). The relations among environmental disclosure, environmental performance, and economic performance: a simultaneous equations approach. Accounting, organizations and society, 29(5-6), 447-471.

Ali, M. J., Ahmed, K., \& Henry, D. (2004). Disclosure compliance with national accounting standards by listed companies in South Asia. Accounting and Business Research, 34(3), 183-199. 
Barakat, F. S., Pérez, M. V. L., \& Ariza, L. R. (2015). Corporate social responsibility disclosure (CSRD) determinants of listed companies in Palestine (PXE) and Jordan (ASE). Review of Managerial Science, 9(4), 681-702.

Boaventura, J. o. M. c. G., R. S. d. Silva, and R. Bandeira-de-Mello. 2012. Corporate Financial Performance and Corporate Social Performance: Methodological Development and the Theoretical Contribution of Empirical Studies. Paper read at R. Cont. Fin. - USP, São Paulo.

Waddock, S. A., \& Graves, S. B. (1997). The corporate social performance-financial performance link. Strategic management journal, 18(4), 303-319..

Chiu, T. K., \& Wang, Y. H. (2015). Determinants of social disclosure quality in Taiwan: An application of stakeholder theory. Journal of business ethics, $129(2), 379-398$.

Ciftci, I., Tatoglu, E., Wood, G., Demirbag, M., \& Zaim, S. (2019). Corporate governance and firm performance in emerging markets: Evidence from Turkey. International Business Review, 28(1), 90-103.

Dowling, J., \& Pfeffer, J. (1975). Organizational legitimacy: Social values and organizational behavior. Pacific sociological review, 18(1), $122-136$.

Guenster, N., Bauer, R., Derwall, J., \& Koedijk, K. (2011). The economic value of corporate eco-efficiency. European Financial Management, 17(4), 679-704.

Guthrie, J., \& Parker, L. D. (1989). Corporate social reporting: a rebuttal of legitimacy theory. Accounting and business research, 19(76), 343-352.

Hitt, M. A., Freeman, R. E., \& Harrison, J. S. (2017). A Stakeholder Approach to Strategic Management. Published Online: 26 NOV 2017: The Blackwell Handbook of Strategic Management.

Ho, V. T., T. V. A. Ho, and T. C. Nguyen. 2017. The corporate environmental responsibility and corporate financial performance: evidences from Vietnamese listed companies. Paper read at Proceedings of ICUEH2017: International conference of University of Economic Ho Chi Minh City: Policies and sustainable economic development., at HCMC, Vietnam, September 28, 2017.

Horváthová, E. (2012). The impact of environmental performance on firm performance: Short-term costs and long-term benefits?. Ecological Economics, 84, 91-97..

Isanzu, J., \& Fengju, X. (2016). Impact of Corporate Social Responsibility on Firm's Financial Performance: The Tanzanian Perspective. Journal on Innovation and Sustainability. 7.

Jamil, M., Zuriana, C., Mohamed, R., Muhammad, F., \& Ali, A. (2015). Environmental management accounting practices in small medium manufacturing firms. Procedia-Social and Behavioral Sciences, 172, 619-626.

Magness, V. (2006). Strategic posture, financial performance and environmental disclosure. Accounting, Auditing \& Accountability Journal, 19(4).

Nelling, E., \& Webb, E. (2009). Corporate social responsibility and financial performance: the "virtuous circle" revisited. Review of Quantitative Finance and Accounting, 32(2), 197-209.

Nguyen, L., \& Tran, M. (2019). Disclosure levels of environmental accounting information and financial performance: The case of Vietnam. Management Science Letters, 9(4), 557-570.

Nguyen, L. S., Tran, M. D., Nguyen, T. X. H., \& Le, Q. H. (2017). Factors Affecting Disclosure Levels of Environmental Accounting Information: The Case of Vietnam. Accounting and Finance Research 6(4).

Nguyen, L. S., Tran, T. H., \& Nguyen, T. N. (2018a). Factors Affecting Disclosure Levels of Environmental Accounting Information: The Case of Vietnam firms doing business under of the model parent company - subsidiary company. Paper read at The 5thIBSM International Conference on Business, Management and Accounting 19-21 April 2018. , at Hanoi University of Industry, Viet Nam.

Nguyen, T. H., Khuu, T. Q., \& Nguyen, N. D. L. (2018b). Determinants of Firm Growth: Evidence from Vietnamese Small and Medium Sized Manufacturing Enterprises. The Journal of Economics and Development (JED) 20 (3).

Ting, N. I. (2017). Disclosure of the environmental accounting information research. DEStech Transactions on Economics, Business and Management, (eced).

Poddi, N. C. L., \& Vergalli, S. (2016). Corporate Social Responsibility and Firms' Performance: a Strategic Graphical Analysis. Journal of International Business and Economics, 4(1), 1-12.

Qiu, Y., Shaukat, A., \& Tharyan, R. (2016). Environmental and social disclosures: Link with corporate financial performance. The British Accounting Review, 48(1), 102-116.

Simpson, W. G., \& Kohers, T. (2002). The link between corporate social and financial performance: Evidence from the banking industry. Journal of business ethics, 35(2), 97-109.

Tauchen, G. (1986). Finite state markov-chain approximations to univariate and vector autoregressions. Economics letters, 20(2), 177-181.

Ullmann, A. A. (1985). Data in search of a theory: A critical examination of the relationships among social performance, social disclosure, and economic performance of US firms. Academy of management review, 10(3), 540-557.

Vo, T. T. A., Ha, X. T. , \& Bui, P. N. K. (2018). What Causes Financial Crisis in Asian Countries? The Journal of Economics and Development (JED) 20(3).

Yang, L.-H., and X.-T. Liang. 2017. Study on the Influencing Factors of Environmental Accounting Information Disclosure. Paper read at International Conference on Economics, Management Engineering and Marketing (EMEM 2017).

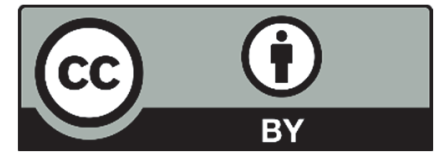

(C) 2020 by the authors; licensee Growing Science, Canada. This is an open access article distributed under the terms and conditions of the Creative Commons Attribution (CC-BY) license (http://creativecommons.org/licenses/by/4.0/). 